\title{
INFORMATION TECHNOLOGY POLICY AND ELECTRONIC GOVERNANCE IN NIGERIA PUBLIC SERVICE: PROBLEMS, AND PROSPECTS
}

\author{
Obikaonu Pauline Chimuru, Ph.D. \\ Email: obikaonu@gmail.com
}

DOI: 10.31364/SCIRJ/v8.i5.2020.P0520774

http://dx.doi.org/10.31364/SCIRJ/v8.i5.2020.P0520774

\begin{abstract}
This study examined and analyzed the information technology policy on the utilization of e-governance in the public service sector. Data utilized for the study were extracted from primary sources i.e. questionnaires and direct interviews. It made use of the Nigerian Public Universities as its case study of public service. The mean, standard deviations were used while the t-test was used to check the assumptions formulated. Empirical results show that information technology policy, in line with theory, exhibits a significant positive impact on e-governance implementation. This shows that given the benefits of e-governance, combating the challenges facing the implementation of e-governance is indispensable in the attainment of sustainable economic development in Nigeria. An increase in government expenditure on improving information technology in all sectors of the economy leads to efficiency and increased productivity of public sectors. As a result of the computed value of the statistical analysis, it was revealed that the low extent of ICT utilization by the public service sector is a critical issue affecting the execution of the e-governance system in Nigeria.
\end{abstract}

Index Terms — information technology policy, electronic governance, Nigeria,

\section{INTRODUCTION}

Information technology is a broadly emphasized concept and a vital feature of a firm's survival and productivity (Farhanghi, Abbapour \& Ghassemi, 2012). They further noted that information technology is a fundamental and integral determinant of firms' support systems, firms' sustainability, and growth of the business. Despite the economic meltdown, the world spending on information technology was estimated at \$US1995.7 billion in 2015 and was projected to be \$US2328.1 billion in 2020 (Statista, 2017). This shows how relevant information technology has contributed to economic growth, springing up new business startups, and a core element to development. One unique aspect of information technology is supporting innovation in all spheres of life especially the business sector (private and public). "The argument concerning the effect of information technology on public service management has brought up lots of controversies among policymakers, researchers and the media" (Liu and Yuan, 2015; Gil-Garcia et al., 2018). A few pieces of research have been directed towards analyzing these effects (positive or negative) (Mimbi \& Bankole, 2016; Scupola \& Zanfei, 2016). Public services are one of the key elements of public administration, enhancing the productivity of public service; which is the government sole aim and objectives (Dan, 2015). He observed that there is less productive in the public sector than the private. However, the yearning for an efficient method and theory for the productivity of public services created an urge to adopt information technology in public services delivery especially in developing countries (Dan, 2015), bringing our attention to this present study to electronic government(E-government).

E-governance system utilizes a bi-modal communication system dealing with the ICT usage to render accessible and available services to the public (Akomaye, n.p). Palvia \& Sharma (2007) also opines that when monitoring and evaluating of public projects are

www.scirj.org

(C) 2020, Scientific Research Journal

http://dx.doi.org/10.31364/SCIRJ/v8.i5.2020.P0520774

This publication is licensed under Creative Commons Attribution CC BY. 
improved, there is transparency, ease of information movement from one sector to another, and accountability improving citizen participation.

Sunday (2014) opined that e-governance has become an important aspect of the political instrument in the evaluation of developmental actions that the government undertakes in developed and developing countries. Thus, information technology usage in public services in promoting the role of government in active participatory democracy, public administration and service delivery has gained ground in the international community (Heeks, 2002)

The role of electronic governance in public service delivery cannot be over-emphasized and cannot be downplayed. It gives the government a competitive advantage in service delivery, making the public system more transparent to an extent, speeds up activities and tasks, and creating room for accountability in public service. The birth of electronic governance in-country can be followed as a result of the establishment in 2000, the Nigeria National Information Technology (NNIT) policy. The designation of the policy was to make an Information Technology vested country in Africa, to be a key player in the world of ICT and also the utilization of information technology for all sectors which include: health, education, governance, and other essential public services (NITP, 2000). Adomi \& Igun (2008) noted that information technology policy is an official statement that explains and pronounces the goal, principles, and strategies among others. The policy regulates and protects the application and operations of Information and Communication Technology (ICT). The introduction of these strategies and policies help ensure that nations of the world harness, deploy and exploit ICTs for socio-economic development at all tiers of government; which enable residents to have access to cheap telephones, broadcasting, computer and internet services (Enakire, 2010).

Based on the above, the present study provides answers to the under-listed questions:

- What is the level of impact of IT-Policy on electronic-governance based on the level of ICT Utilization in Public Nigerian University by Students?

- What is the level of impact of IT-Policy on electronic-governance based on the level of ICT Utilization in Public Nigerian University by Non-Academic staff?

- What is the level of impact of IT-Policy on electronic governance based on the level of ICT Utilization in Public Nigerian universities by Academic staff?

\section{THE CONCEPT OF INFORMATION TECHNOLOGY POLICY IN NIGERIA}

Nigeria is a developing country with a rich cultural, natural, and human resources heritage. As a developing country, it has a vision to improve in International Information Technology (IT) business thereby adding positive value to the nation's (Nigeria) economy. Its driving factor is to present Nigeria as a competent nation fit for recognition by international IT companies through the establishment of better structures. As an enabling tool for economic development, the government that promotes IT in various sectors of its economy as well as managing its Natural resources. This will promote the multi-faceted structure of e-government services aimed at actualizing good governance and increase productivity/service delivery. (NITDA, 2012). According to NITDA (2018), the aim and objectives of ICT National policy, however, is to provide a model that designs the ICT sector, enhancing the capacity for socioeconomic development to be sustained and developed, which is, thus, vital to the country's vision of becoming a top20 economy by the year 2020. Synonymously, the policy is set to improve the transformation of the country into an economy that is knowledge-based and being used as a tool for a development action plan.

ICT sector development in Nigeria was far below expectation, before 1999, given the country's size and resources. For instance, we had approximately 400,000 total fixed telephone lines and approximately 200,000 regular users of the internet. Based on the standpoint of policy and regulations, the National Telecommunication Policy (NTP) was adopted in 2000 to supervise the development of the telecommunication sector in Nigeria. This paved way for the introduction of the Nigeria Communication Act (NCA) in 2003 to provide a legal effect to NTP. Before that, the recommendation was made by the National Mass Communication

www.scirj.org

(C) 2020, Scientific Research Journal

http://dx.doi.org/10.31364/SCIRJ/v8.i5.2020.P0520774

This publication is licensed under Creative Commons Attribution CC BY. 
Policy for the creation of a regulatory body for broadcasting, leading to the promulgation of Decree 38 of 1992 which finally gave birth to the National Broadcasting Commission (NBC).

Similarly, the approval of the National Information Technology Policy in 2001 was to regulate and guide the Information Technology industry in Nigeria, coupled with the enactment in 2007, the National Information Technology Development Agency Act; the platform that led to the establishment of the National Information Technology Development Agency (NITDA). It is vital to note that there has never been a National Postal policy; thus, Decree No. 41 of 1992 established the Nigeria Postal Service (NIPOST) to provide postal services to Nigerians.

The development of these policies and regulations together with other public and private sectors has led to a significant improvement in the ICT sector in Nigeria. For example, the country has progressed from an initial less than 400,000 available fixed telephone lines in 1999 to more than 90.5 million available mobile telephone lines by 2011 first quarter (Q1), which made the country's telecommunication industry the fastest growing in Africa. The deployment of ICT in the government sector and the private sector is now modest. Information Communication Technology is now a driver of most activities in both the financial and oil and gas sector while several initiatives of e-government are still ongoing in different departments across the levels of government in Nigeria.

\section{THE CONCEPT OF E-GOVERNANCE}

E-governance as a concept varies with broad and several definitions specifically as it deals with public service delivery. The different definition has been presented by researchers and experts of ICT to explain the concept. Scholars such as Shilubane (2001); Budhiraja (2003); Ayo (2014); and Ojo (2014). Shilubane (2001) noted that e-governance is defined as the utilization of information and communication technologies (ICTs) for public services which implies the use of the internet to enhance service delivery in a much more convenient, cost-effective and people-oriented manner. Budhiraja (2003) defines e-governance as the use of Information Technology to the functioning of the government process to achieve a SMART (Simple, Moral, Accountable, Responsive, and Transparent) governance.

As noted by Ayo (2014), electronic governance is the use of ICT to govern a state or country. This implies that e-governance is implementing activities of government through the adoption of ICT. Also, Ojo (2014) opined that electronic governance is the use of ICT by the public sector to improve awareness, accountability, and transparency in management and controlling the governmental business. Furthermore, he posited that electronic governance can be utilized as a government strategy through publicizing activities.

Based on the above definitions, electronic governance is the implementation/usage of ICTs in the running of government set agendas. This, however, implies a shift from the conventional method of carrying out government-oriented tasks which are usually in a linear or hierarchical structure to internet-based government activities, providing access to a wealth of information at their own pace.

Dada (2006) asserts that e-government is more than just a website of government parastatals and ministries on the internet or government computerized activities, but the ability to use technologies to detect the high extent of improvement in e-governance.

The e-government objectives are to satisfy the public's needs and expectations through the following;

- Simplify citizens, businesses, and other agencies' interactions with various online services.

- Facilitate speedy availability and access to information.

- Encourage transparent and accountable governing system

- Promote effective and efficient administrative processes and interaction with the public, citizens, businesses, and other agencies.

www.scirj.org

(C) 2020, Scientific Research Journal

http://dx.doi.org/10.31364/SCIRJ/v8.i5.2020.P0520774

This publication is licensed under Creative Commons Attribution CC BY. 
Reiterating on what was mentioned earlier, electronic governance objectives are meant to simplify and support governance for the three targeted groups which are considered in the e-governance concept; government, citizens, and business/interest groups. Usage of ICT fosters the connections among all these three essential parties and support processes and activities. Thus, this implies that egovernance makes use of an electronic method as a supporting structure to stimulate good governance. The e-governance objectives are likening to that of good governance. According to Heeks (2001), the use of economic, political, and administrative authority to effectively manage the country's affairs at all tiers of government is referred to as good governance. Connecting citizens, improving government administration, and build interaction with the external environment (e-society).

\section{THE IMPACT OF INFORMATION TECHNOLOGY POLICY ON ELECTRONIC GOVERNMENT}

\section{Skilled manpower}

The training of individuals is a prerequisite for sufficient use of ICTs in the organization. Where the individuals feel insecure and uncomfortable with the tools they may, however, turn to their previous working style and habits. In the maintenance of ICTs infrastructure, knowledge of the resources is required. Competition between government and the private (commercial) sector is at its peak in other to employ experienced personnel.

\section{$\underline{\text { Need for information }}$}

Websites contain information. Information is accumulated, generated, and updated daily by the government. Phase 1 has contents, however, there are constant changes in phase 2 . It should be noted that the responsibility for information on the website is solely that of the content managers in various departments.

\section{Guarantee}

Every computer system is prone to external attacks. As the transfer of important processes (information, communication, and transaction) by the government to the internet is carried on, exposure to external attacks is highly feasible because there is an increase in the number of entry points exponentially by the internet. Protection is feasible with a firewall at gateways, encryption technology, authentic identification tools, and anti-virus software.

\section{$\underline{\text { Constant model service }}$}

The expectations of the citizenry towards the attentiveness of government will witness a new change because the new channel of communication has to correspond with systems and processes of a completely new service model, whereby the input processes are self-service made and in the middle of the night still a citizen could get a fast response on issues about the status of an application.

\section{$\underline{\text { Privacy }}$}

Due to the interest of the citizens regarding privacy, many countries had passed the laws of data protection where the privacy of the citizens is endangered in the event of integration of data, the government must restrict the use of private information. In phases 3 and 4 extensive information about citizens and businesses is controlled by the government, which many times are held in multiple complexes on different computers (or available in paper files).

\section{THE CHALLENGES HINDERING THE EFFECTIVE IMPLEMENTATION OF ELECTRONIC GOVERNANCE}

www.scirj.org

(C) 2020, Scientific Research Journal

http://dx.doi.org/10.31364/SCIRJ/v8.i5.2020.P0520774

This publication is licensed under Creative Commons Attribution CC BY. 
Kumar, M. (2020); Dwivedi and Bharti (2005); Heeks (2009) and; Mittal and Kaur (2013) caution that increased manpower cost, organizational resistance, poverty, language dominance, legal infrastructure, leadership, and strategic thinking all connive to serve as a clog in the wheels of effective e-governance. However, a note should be taken that inadequacies relating to privacy and security are only latent consequences of e-governance. On the whole, challenges to effective e-governance are socio-cultural, economic, political, and institutional.

\section{Inadequate trained and qualified personnel to handle and operate its infrastructures:}

Over the years, the government has been reluctant to actually executing and fully adopting e-governance in public service delivery as a result of procurement high cost and empowerment and training of public servants in ICT skills. As noted by Ayo \& Ekong (2008), successful and efficient implementation of e-governance requires experts to effectively coordinate and operate the ICT infrastructures. Also, Galal-Edeen (2008) emphasized the detriment of the inadequately skilled workers in handling different services of ICT and their usage in bringing about the successful execution of e-governance in the public sector.

\section{Low level of ICT literates:}

ICT has gained less prominence in Nigeria because most Nigeria views computer literates as fraudsters and the use of computers to be very complex to be understood. Therefore, they are not interested in acquiring ICT knowledge. Also, the cost of a PC in Nigeria is five times the monthly wage of an average worker, the high cost of the subscription to get internet access. These are major challenges facing the implementation of e-governance.

\section{The resistance of e-governance by political leaders:}

Political leaders within government circles do everything possible to frustrate the process of implementing e-governance because they want to continue milking from the country's resources. The policy has suffered negligence from the government due to the strong political unwillingness and determination to ensure that the government fails in her ICT goal which is evident in the poor allocation of resources for and the development of ICT systems in the country.

\section{Lack of infrastructural facilities and irregular power supply:}

Most public offices still carry out their daily task manually with the use of papers because of the lack of ICT facilities such as computers, access to the internet, and irregular power supply. Gberevbie; Ayo; Iyoha; Duruji \& Abasilim (2015) supports the need for establishing the required infrastructure such as telecommunications and computer hardware, internet connectivity, regular power supply, cables of optical fiber among others, for the successful execution of electronic governance. According to Okwueze (2010), an adequate supply of power is an important feature that must be taken into consideration for the effective implementation of egovernance in Nigeria's public service.

\section{Inadequate government regulatory policy}

The Inadequacy of government regulatory policy is an essential tool that must be addressed for effective execution of e-governance in the public sector. Despite the policies regarding ICT and E-governance, the implication of the situation remains that ICT services from the government are not adequately regulated.

www.scirj.org

(C) 2020, Scientific Research Journal

http://dx.doi.org/10.31364/SCIRJ/v8.i5.2020.P0520774

This publication is licensed under Creative Commons Attribution CC BY. 


\section{THE MEASURES THAT WILL ENSURE EFFECTIVE ELECTRONIC GOVERNANCE THROUGH ITS POLICY}

According to Godse \& Garg (2009), the following measures are to be considered in the implementation and attainment of success ful e-governance

- Making and implementing decisions

- Proper leadership

- Placement of organizational arrangements to ensure resources and funding

- Establishing accountable success measurement

- Assessment of telecommunications network

- Assessment of internal agency

- Internet accessibility and skillfulness of staff

- Cross-examining government systems

- Accessing points of service delivery network

- Improve interactions with business and industry

- Empowerment of citizens through access to information

- Efficiency in government management

\section{Modeling of e-governance}

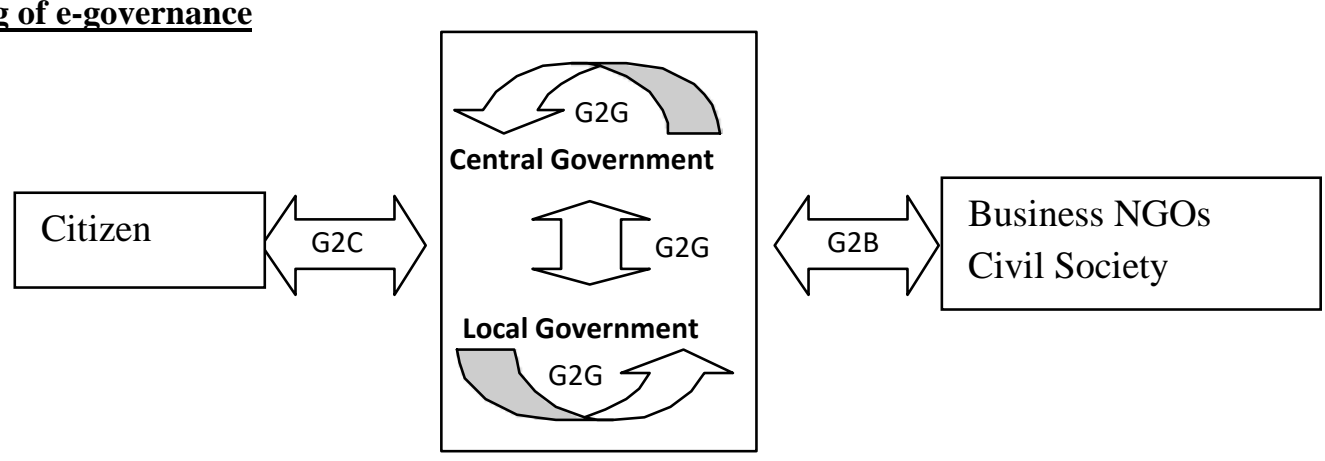

Figure 1: $\underline{\text { Interaction between the three main target groups }}$

Source; Backus, 2001.

\section{(G2G- Government to Government)}

Interactive knowledge databases, complaint handling tools, inter-governmental transactions, and database integration.

www.scirj.org

(C) 2020, Scientific Research Journal

http://dx.doi.org/10.31364/SCIRJ/v8.i5.2020.P0520774

This publication is licensed under Creative Commons Attribution CC BY. 


\section{(G2C- Government to Citizens)}

Complete transactions are performed online without visiting an office, for example, extending/renewal of licenses, visa, and passports, renewing car tags, vehicle registration personal accounts (my tax, my fines, my licenses among others), payment of property taxes, payment of tickets and fines, paying utility bills, registering and voting online. Finally, newsletters, discussion groups (e-democracy) polls \& questionnaires and personalized website with an integrated personal account for all services

\section{(G2B- Government to Businesses)}

The government implements the use of e-procurement applications, License applications, and renewals via the website for businesses. Also, the use of a personalized website with integrated business accounts for all services.

\section{THE BENEFITS ASSOCIATED WITH ELECTRONIC GOVERNANCE}

\section{$\underline{\text { An efficient and effective system }}$}

For complete transactions to be performed online without visiting an office, for example, extending/renewal of licenses, visa, and passports, renewing car tags, vehicle registration personal accounts (my tax, my fines, my licenses among others.), payment of tickets and fines, paying utility bills for citizens and also use of e-procurement applications, license applications, and renewals via the website for businesses.

\section{$\underline{\text { Improved reputation due to an accountable and transparent governance }}$}

E-governance is a veritable tool for improving accountability and transparency. This is because it eliminates or reduces to the barest minimum the chances of official graft, embezzlement, and other corrupt practices. This also boosts the citizen's confidence and allegiance to her government.

\section{$\underline{\text { Access to Information }}$}

ICT Platforms can be used in providing information to the citizens by the government on the jobs' vacancies, prospective employers, and requirements. It can also be used to communicate government decisions and other social/welfare services.

\section{E-security System}

E-governance allows for all citizens to provide their Personal and property information in its database, this gives access to information to security agents which can be used to trace and control criminal activities.

\section{$\underline{\text { Economic Growth and Development }}$}

National development becomes possible because the local and state government is strategically positioned to compete favourably and attract foreign direct investment. This investment leads to the development of localities and the accrued benefits trickle down even to the poor.

The Nigerian National Information Technology Policy outlines the following as prospects of e-governance

www.scirj.org

(C) 2020, Scientific Research Journal

http://dx.doi.org/10.31364/SCIRJ/v8.i5.2020.P0520774

This publication is licensed under Creative Commons Attribution CC BY. 
- Replaces traditional governance with electronic governance.

- Creates knowledge-based and Simple Moral Accountable Responsive and Transparent (SMART) governance.

- Reduce bureaucracy.

- Maximizes productivity and quality.

- Eliminates waste.

- Increase inefficiency.

- It creates easy and free access to government information.

- Reduces the cost of service delivery.

\section{THE THEORETICAL FRAMEWORK OF ELECTRONIC GOVERNANCE}

In portraying the contributions of e-governance to an organization's growth, the United Nation's (2002) E-governance Progress Measurement Model and the Gartner Group's (2000) E-governance Maturity Model stand out. The Gartners (2000) model will be succinctly discussed and adopted as its theoretical framework as well as the discussion of other models.

\section{E-governance Progress Measurement Model}

Five stages (Savic, 2006) were developed for measuring advancements toward e-governance made by public organizations by the United Nations (UN) in one of its E-governance Surveys at the turn of the millennium. The undermentioned stages are believed by the U.N to be the steps for which every e-governance framework and strategy must follow to develop and be effective.

1. Emerging Web Presence - One or a few websites offering static information.

2. Enhanced Web Presence -Growing numbers of web pages offering dynamic information.

3. Interactive Web Presence - Exchanges between users and governments (electronic form).

4. Transactional Web Presence - Services such as purchases (licenses) and payments (taxes).

5. Fully Integrated Web Presence - Combination of information exchanges and services.

The model provides that organizations pass through these strategized stages to make it to the highest of e-governance which is the ultimate effectiveness of the system. Critics believe some public organization although undergo these stages, they many times do so

www.scirj.org

(C) 2020, Scientific Research Journal

http://dx.doi.org/10.31364/SCIRJ/v8.i5.2020.P0520774

This publication is licensed under Creative Commons Attribution CC BY. 
not in a sequence. For example, from emerging web presence, an organization may migrate to interactive web presence before enhancing web presence.

\section{E-governance Maturity Model}

In the year 2000, the Garner Group a renowned international consultancy firm developed this model. Governments and other stakeholders are given a position in the four-phase e-governance model where a project fits in the overall evolution and effectiveness of an e-governance strategy (Patil, 2011). Savic (2006), the government begins the conveying of wire news however, public requests, as well as intricate services, are needed when it comes to internal services. ICT governance projects translate on a steady and gradual order to carter to those requests. There are a retrace and retrospection at the end of every phase but within a possible frame of time and money, although the model views e-governance maturity in four phases. The pertinent needs of all e-governance stakeholders are served in each step on the design and purpose (Patil, 2011).

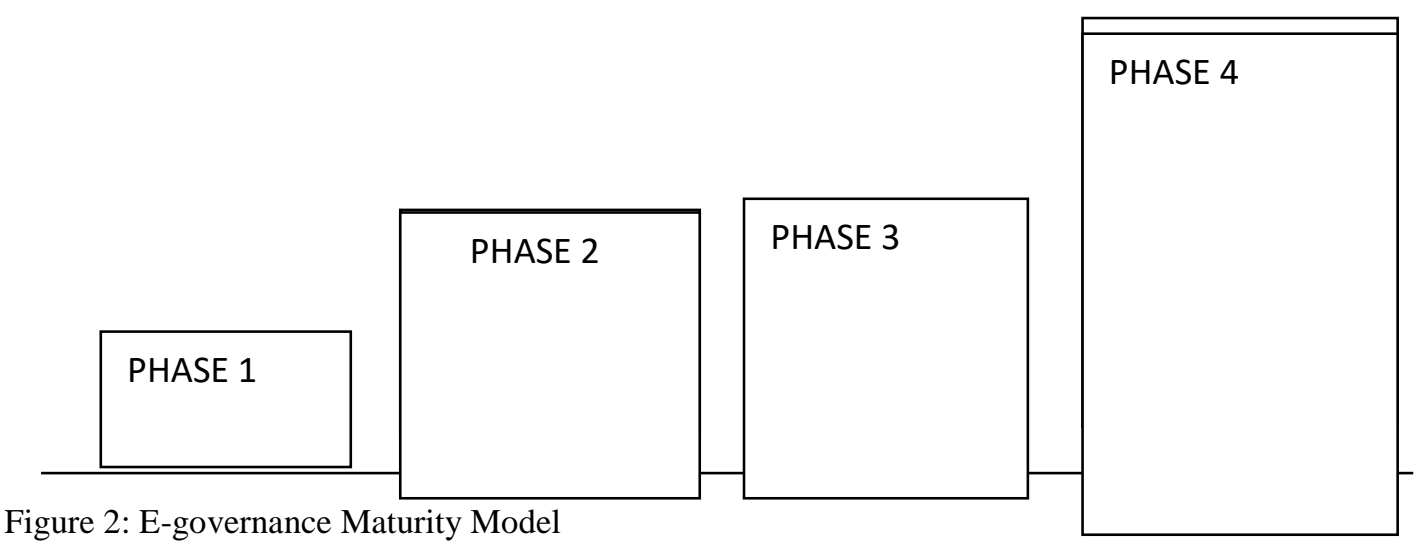

Source: Savic, D. (2006) E-governance: Theoretical Foundations and Practical Implications, pp.38

Phase 1: Information

In this segment, the government publicizes its purpose through creating a website or a network of sites set apart for different ministries, departments, and agencies (MDAs). In these sites, the initiatives of the government are relayed thus, information relating to official working hours and forms to the citizenry, corporate regulations for businesses and economic reviews; budgetary allocations, and spending to government establishment. Just as a leaflet, the relevant information is stipulated in these sites for the comfort of the general public (Savic, 2006; Patil, 2011).

Phase 2: Interaction

The interaction between government and its stakeholders i.e. citizens, business, and MDAs begins here in this phase, signals advancement. Activities are carried on online without the stress of visiting government counter during working hours; this phase provides navigation for ease of interaction and some search engines for locating information and downloading documents (Savic,

www.scirj.org

(C) 2020, Scientific Research Journal

http://dx.doi.org/10.31364/SCIRJ/v8.i5.2020.P0520774

This publication is licensed under Creative Commons Attribution CC BY. 
2006; Patil, 2011). It was noted by Savic (2006) that, the citizens and businesses still have to visit the government office to conclude transactions by handing over evidence or signing papers. MDAs use Local Area Network (LAN) intranets and email to communicate and exchange data.

Phase 3: Transaction

Before phases 3 and 4 are to commence, the duty of building the fundamental information in phases 1 and 2 could have to be sustained particularly by technical staff. As e-governance technology grows complex at this phase, citizens, businesses, and MDAs can now commence and finalize transactions without having to visit a government office. Patil (2011) warned that for the possibility of this phase to be attained, internal processes have to be restructured and new laws to enhance online business with legitimate documentation be implemented. Payments, licenses, digital initials, online procurement tax returns among others are all feasible in this phase (Savic 2006).

Phase 4: Transformation

This is the last phase which is aimed at realizing the true goal of e-governance. In other words, cost savings, effectiveness, and customer satisfaction are to be at the highest feasible levels. This phase stands unique in that all government information systems are united and thus citizens and businesses can get all required services at one virtual counter. However, major cultural change, process re-engineering, and responsibilities redefinition within the institutions of government are the background (Savic, 2006).

The importance of Gartner's (2000) e-governance maturity model to our study rests in its idea of gradual and steady movement of egovernance strategies which determines the effectiveness or otherwise of the initiative. Put differently, e-governance according to the Model evolves through the four phases of information (ICT infrastructure), interaction (ICT utilization), transaction, and transformation.

\section{THE EMPIRICAL REVIEW OF RELATIONSHIP BETWEEN IT-POLICY AND PROPER APPLICATION OF ICT GOVERNANCE IN THE PUBLIC SERVICE}

Fatile (2012) in her paper examines e-governance as a myth or opportunity for Nigerian Public Administration. The objective of the research was to assess the implementation levels of e-governance in Nigeria. An evaluation of the factors to achieve success in the implementation and analysis of the impact of e-governance in service provision in Nigeria. The research was conducted using secondary data and the results showed that Nigeria is faced with several challenges concerning e-governance which includes inadequate ICT infrastructures and limited access to internet usage by the citizens. The recommendation from this research was that the government should declare access to ICT services as a fundamental human right of every Nigerian and to create an enabling environment and schedule required to allure proper capital. In conclusion, this work expressed a high level of confidence in the potency of e-governance in transforming the internal efficiency of government and the allegiance of citizens to its government.

However, the results of the study by Fatile (2012) are correct but it has some defects in terms of scope. The first defect is the paper didn't define the period covered by the study. Rather than emphasize just the implementation, success factors, and challenges in the study, the selected variable of interest to the study should have been brought into consideration, for example, the ICT infrastructures which serve as the initial take-off for e-governance. The second defect is the ambiguity in attempting to study the entire Nigerian public administration instead of a few selected organizations.

www.scirj.org

(C) 2020, Scientific Research Journal

http://dx.doi.org/10.31364/SCIRJ/v8.i5.2020.P0520774

This publication is licensed under Creative Commons Attribution CC BY. 
Ojo(2014) in research on the imperative of electronic governance for sustainable development in grassroots in Nigeria use data that were obtained from secondary sources. The research found electronic governance to enhance participation, transparency, correspondent also wide equality to facilitate grassroots development; e-governance is used in the facilitation of proper discussion by the leaders with their people at the local level; and opens an avenue where populace gains feedback from a felicitous channel. Therefore, it was decided that e-governance guarantees effective and efficient service delivery and facilitates the indulgence of the populace in local affairs. The adoption of ICT and training of local government workers for sustainable grassroots development was approved by the research to the Federal Government for implementation.

Ojo's (2014) research did not explicitly define the e-governance variables which the research concentrated on. The reason being that e-governance is an oddity that cannot be properly documented. Variables such as ICT infrastructure, ICT literacy, ICT staffing among others were not shortlisted in this research for examination. The research had its interest in e-governance at the grassroots level, it is not explicitly provided for as to which of the 774 local governments in Nigeria. Also, the scope of the research concerning time was not stated.

Madugu (2012) also researched the Application of ICT in the conduct of government business and its implication on bureaucracy. The examination as to the extent to which ICTs promotes the delivery of public goods and services was the objective of this research. Data were obtained from secondary sources. The work revealed that ICTs in government gives room for extensive public participation and contribute toward efficient service delivery. He approved that more ICTs tools should be assigned by the government to facilitate service delivery and the use of ICTs should have national coverage to bridge the digital divide in the country.

Government business is so wide that this research ought to have limited itself to a certain aspect of it. Also, the variables showing the use of ICT by the government were not established. In full, the scope of this research is faulty in aspects of time, materials, and area.

\section{RESEARCH METHODOLOGY}

This study adopts the survey research method. This design focuses on a sample drawn from a population and the data collected through questionnaires and direct interviews. The choice of survey design is because it is cost-friendly, less time consuming, and convenient. This work is construed to evaluate IT-Policy impact on electronic governance in public service. It made use of Public Nigerian University students and staff. In this research, the variables relating to e-governance such as the availability of ICT infrastructures, accessibility to the internet, level of ICT utilization by students, and staff were examined using a five-point Likert scale of measurement.

However, the primary source of data (specifically questionnaire) was used. The population size is divided into three categories:

a) Public Nigerian University Students

b) Public Nigerian University Academic staff

c) Public Nigerian University Non-academic staff

Each category consists of 200 individuals from 10 different Public universities in Nigeria (each university having 20 per category using the simple random technique). The method of data analysis used in this study is the quantitative approach. The mean and standard deviation were the statistical tools used in the data analysis, meanwhile t-test was used to check the assumptions formulated.

www.scirj.org

(C) 2020, Scientific Research Journal

http://dx.doi.org/10.31364/SCIRJ/v8.i5.2020.P0520774

This publication is licensed under Creative Commons Attribution CC BY. 


\section{RESULTS, CONCLUSION ALSO RECOMMENDATION}

\section{RESULTS}

Here, research questions, as well as the null hypotheses, are being raised from the result of the work. The presentation was done according to the trend of the three research questions and hypotheses guiding the study.

\section{Research Question 1.}

What is the level of impact of IT-Policy on e-governance concerning the low level of ICT Utilization by Public Nigerian University Students?

Table 1: Mean of responses on the impact of IT-Policy on e-governance as a Public Nigerian Student $\left(\mathrm{N}_{1}=100, \mathrm{~N}_{2}=100\right)$

\begin{tabular}{|l|l|l|l|l|l|l|}
\hline S/N & Student ICT Utilization & $\overline{\mathbf{X}}_{\mathbf{1}}$ & $\overline{\mathbf{X}}_{\mathbf{2}}$ & $\mathbf{S D}_{\mathbf{1}}$ & $\mathbf{S D}_{\mathbf{2}}$ & $\mathbf{D e c i s i o n ~}$ \\
\hline 1. & Poor accessibility of internet facilities by Nigerian Students & 3.23 & 3.27 & .59 & .57 & $\mathrm{G} 1$ \\
\hline 2. & Poor quality of internet access available to Nigeria University students & 3.21 & 3.36 & .76 & .74 & $\mathrm{G} 1$ \\
\hline 3. & Less confidence in transactions with Universities e-portal & 3.13 & 3.28 & .68 & .72 & $\mathrm{G} 1$ \\
\hline 4. & Low speed of transaction with universities e-portal & 3.17 & 3.14 & .83 & .81 & $\mathrm{G} 1$ \\
\hline & Grand mean & 3.19 & 3.26 & & & G1 \\
\hline
\end{tabular}

GI= Great Influence; Source: Field data (2020)

The result presented in Table 1 showed that the mean $(\overline{\mathrm{X}})$ scores of items 1 to 4 and the grand mean shows that Nigerian Students ICT Utilization is very low. The table shows that the standard deviation of the items fell within the range of 0.57 to 0.83 . It also indicates that the students have divergent views on ICT.

\section{Research Question 2.}

What is the level of impact of IT-Policy on e-governance concerning the low level of ICT Utilization by Public Nigerian University Non-Academic staff?

Table 1: Mean of responses on what level of impact does IT-Policy have on e-governance as a Public Nigerian Universities Non-Academic staff. $\left(\mathrm{N}_{1}=100, \mathrm{~N}_{2}=100\right)$ 


\begin{tabular}{|c|c|c|c|c|c|c|}
\hline $\mathbf{S} / \mathbf{N}$ & Nigerian Universities Non-Academic staff ICT Utilization & $\overline{\mathbf{X}}_{1}$ & $\overline{\mathbf{X}}_{2}$ & $\mathbf{S D}_{1}$ & $\mathbf{S D}_{2}$ & Decision \\
\hline 1. & Unavailability of ICT Facilities & 2.64 & 2.78 & .82 & .88 & GI \\
\hline 2. & Poor quality of internet access available to Non-Academic staff & 3.42 & 3.56 & .42 & .47 & GI \\
\hline 3. & Low skillfulness and knowledge on ICT & 3.97 & 3.81 & .47 & .41 & VGI \\
\hline 4. & Poor Distribution of ICT Knowledgeable staff & 3.12 & 3.07 & .65 & .61 & GI \\
\hline & Grand mean & 3.28 & 3.31 & & & GI \\
\hline
\end{tabular}

VGI= Very Great Influence; GI= Great Influence; Source: Field data (2020)

The result presented in Table 2 showed that the mean $(\bar{X})$ scores of items 1 to 4 and the grand mean shows that the impact of ITPolicy on e-governance based on the ICT Utilization by Non-Academic staff is not significant. Items 1,2 and 4 show the unavailability of ICT Facilities, poor quality of internet access and lack of knowledge on ICT by the Public Universities NonAcademic staff and these reflect the major challenges facing e-governance. The table also shows that the standard deviation of the items fell within the range of 0.41 to 0.88 . This indicates that the respondents have divergent views on the questions asked.

\section{Study Inquiry 3.}

Discuss the impact of IT-Policy on electronic governance concerning the low level of ICT Utilization by Public Nigerian University Academic staff?

Table 3: Mean of responses on what level of impact does IT-Policy has on e-governance as a Public Nigerian Universities Academic staff. $\left(\mathrm{N}_{1}=100, \mathrm{~N}_{2}=100\right)$

\begin{tabular}{|l|l|l|l|l|l|l|}
\hline S/N & Public Nigerian Universities Academic staff ICT Utilization & $\overline{\mathbf{X}}_{1}$ & $\overline{\mathbf{X}}_{\mathbf{2}}$ & $\mathbf{S D}_{\mathbf{1}}$ & $\mathbf{S D}_{\mathbf{2}}$ & Decision \\
\hline 1. & Unavailability of ICT Facilities & 2.84 & 3.01 & .72 & .63 & GI \\
\hline 2. & Poor quality of internet access available to Non-Academic staff & 2.72 & 3.28 & .96 & .83 & GI \\
\hline 3. & Low skillfulness and knowledge on ICT & 3.15 & 3.27 & .64 & .55 & GI \\
\hline 4. & Poor Distribution of ICT Knowledgeable staff & & & & & \\
& & 3.09 & 3.61 & .71 & .83 & GI \\
\hline
\end{tabular}

www.scirj.org

(C) 2020, Scientific Research Journal 


\begin{tabular}{|l|l|l|l|l|l|l|l|}
\hline & Grand Mean & 3.01 & 3.29 & & & GI \\
\hline
\end{tabular}

GI= Great Influence; Source: Field data (2020)

The result presented on Table 3 showed that the mean $(\bar{X})$ scores of item 1 to 4 and the grand mean shows the responses on the level of impact of IT-Policy has on e-governance using the Public Nigerian Universities Academic staff ICT Utilization. The table shows that the standard deviation of the items fell within the range of 0.55 to 0.96 .

\section{Research Hypothesis 1}

There is no significant impact of IT-Policy on e-governance based on the ICT Utilization by

Public Nigerian University Students

Table 4: t-test analysis showing the responses on what impact does IT-Policy has on e-governance as a Public Nigerian University Student.

\begin{tabular}{|l|l|l|l|l|l|l|l|}
\hline Variable & $\mathrm{N}$ & $\overline{\mathrm{X}}$ & $\mathrm{SD}$ & $\mathrm{DF}$ & $\mathrm{t}-\mathrm{cal}$ & $\mathrm{P}>0.5$ & Decision \\
\hline Male & 100 & 13.23 & 1.43 & & 2.19 & .073 & \\
\hline Female & 100 & 13.56 & 1.45 & 198 & & & $* *$ \\
\hline
\end{tabular}

**= Not significant @ p >.0.5, Source: Field Work (2020)

Table 4 gives a summary of the t-test analysis of the mean responses of male and female students on the impact of IT-Policy on egovernance as a Public Nigerian University Student. The result shows that the respondents were not statistically significant with ( $t$-cal 2.19, $\mathrm{p}<.073 @ \mathrm{df}$ 198) since the p-value is higher than.05 alpha level there is no significant difference between the mean of the respondents.

\section{Research Hypothesis 2}

There is a significant impact of IT-Policy on e-governance based on the ICT Utilization by Public Nigerian University Non-Academic staff

Table 5: t-test analysis showing the responses on what impact does IT-Policy has on e-governance as a Public Nigerian University Non-Academic staff.

www.scirj.org

(C) 2020, Scientific Research Journal

http://dx.doi.org/10.31364/SCIRJ/v8.i5.2020.P0520774

This publication is licensed under Creative Commons Attribution CC BY. 


\begin{tabular}{|l|l|l|l|l|l|l|l|}
\hline Variable & $\mathrm{N}$ & $\overline{\mathrm{X}}$ & $\mathrm{SD}$ & $\mathrm{DF}$ & $\mathrm{t}-\mathrm{cal}$ & $\mathrm{P}>0.5$ & Decision \\
\cline { 1 - 6 } Male & 100 & 13.45 & 1.43 & & 3.12 & .070 & \\
\cline { 1 - 5 } Female & 100 & 13.11 & .95 & \multirow{2}{*}{198} & & & $* *$ \\
\hline
\end{tabular}

**= Not significant @p >.0.5, Source: Field Work (2020)

Table 5 gives a summary of the t-test analysis of the mean responses of male and female staff on the impact of IT-Policy on egovernance as a Public Nigerian University Non-Academic staff. The result shows that the respondents were not statistically significant with (t-cal 3.12, p<.070@df 198) since the p-value is higher than .05 alpha level there is no significant difference between the mean of the respondents. Hence, the null hypothesis which stated that there is no significant influence is accepted.

\section{Research Hypothesis 3}

There is a significant impact of IT-Policy on e-governance based on the ICT Utilization by Public Nigerian University Academic staff

Table6: t-test analysis showing the responses on what impact does IT-Policy has on e-governance as a Public Nigerian University Academic staff.

\begin{tabular}{|l|l|l|l|l|l|l|l|}
\hline Variable & $\mathrm{N}$ & $\overline{\mathrm{X}}$ & $\mathrm{SD}$ & $\mathrm{DF}$ & $\mathrm{t}$-cal & $\mathrm{P}>0.5$ & Decision \\
\hline Male & 100 & 13.45 & 1.43 & & 3.12 & .070 & \\
\hline Female & 100 & 13.11 & .95 & 198 & & & $* *$ \\
\hline
\end{tabular}

**= Not significant @p>.0.5, Source: Field Work (2020)

Table 6 gives a summary of the t-test analysis of the mean responses of male and female staff on the impact of IT-Policy on egovernance as a Public Nigerian University Academic staff. The result shows that the respondents were not statistically significant with (t-cal 3.12, p<.070@ df 198) since the p-value is higher than .05 alpha level there is no significant difference between the mean of the respondents. Hence, the null hypothesis which stated that there is no significant impact is accepted.

\section{CONCLUSION}

Considering the benefits that come with e-governance, it can be concluded that the non-implementation of e-governance is a key factor responsible for Nigeria's economic underdevelopment. From the results of this work, our conclusion is IT infrastructure needed for e-governance in Nigerian universities was qualitatively low. The level of student and staff utilization of ICT facilities in the Public

www.scirj.org

(C) 2020, Scientific Research Journal

http://dx.doi.org/10.31364/SCIRJ/v8.i5.2020.P0520774

This publication is licensed under Creative Commons Attribution CC BY. 
Nigeria Universities was equally low. It can also be concluded that there is an insignificant relationship between IT-Policy and egovernance in Nigeria's public sector.

Following the presentation and analyses of data as well as tests of hypothesis, this study shows that to achieve successful egovernance, there must be sufficient provision of ICT facilities, quality access to the internet, and regular training on ICT utilization. Therefore, throughout this study, IT-Policy and e-governance were less effective.

The first hypothesis test indicated that low-level utilization of ICT by Public Nigerian University students impedes the impact of ITPolicy on e-governance. The second hypothesis concludes that low-level utilization of ICT by Public Nigerian Universities NonAcademic staff impede the impact of IT-Policy on e-governance. Lastly, the third hypothesis that low-level utilization of ICT by Public Nigerian Universities Non-Academic staff also hinders the impact of IT-Policy on e-governance in the public sector.

\section{RECOMMENDATIONS}

In the results from the work, there has been a commendation in other to make the IT-Policy significant in the execution of electronic governance in the public sector to enhance economic development.

- Effective and functional ICT knowledge acquisition centers should be established in every local government of each state for citizens to be adequately trained

- The education system in Nigeria should be overhauled and properly enhanced with ICT Infrastructures and regularly train its staff and students. Federal, State, and Local government should make provision for this specifically.

- The Health System in Nigeria should be adequately and properly facilitated with ICT infrastructure and regularly train its staff. Federal, State, and Local government should make provision for this in its annual budget.

- The aviation industry should be adequately and properly facilitated with ICT infrastructure and regularly train its staff

- Communication industry should be adequately and properly facilitated with ICT infrastructure and regularly train its staff

- The agricultural sector should be adequately and properly facilitated with ICT infrastructure and regularly train its staff

- All ministries, departments, and agencies should be adequately and properly facilitated with ICT infrastructure and regularly train its staff

- The government should take up the responsibility of providing regular power.

- The government should monitor the implementation of e-governance and regularly review IT-Policy

\section{References}

Adomi, E. E., \& Igun, S. E.(2010). ICT policies in Africa. In Networking and Telecommunications: Concepts, Methodologies, Tools, and Applications (pp. 729-735). IGI Global. Retrieved 17 April, 2020, from https://www.igi-global.com/chapter/ict-policiesafrica/49771

Akomaye, A.B. (n.p). The status and nature of e-governance in nigeria. Retrieved $17 \quad$ April, 2020 , from http://eprints.covenantuniversity.edu.ng/5267/1/ADAH\%20BENYIN\%20A

Ayo, C. K. (2014). Information and Communication Technology as a Lever for Innovation in Leadership. In: T. Abioye, C. Awonuga and A. Amuwo (eds), Leadership and Innovation in Africa's Development s Paradigm. Otta: Covenant University Press.

Budhiraja, R (2003). Electronic Governance - A Key Issue in the 21st Century, Additional Director,

www.scirj.org

(C) 2020, Scientific Research Journal

http://dx.doi.org/10.31364/SCIRJ/v8.i5.2020.P0520774

This publication is licensed under Creative Commons Attribution CC BY. 
Electronic Governance Division, Ministry of Information Technology, Government of India.

Available: http://www.mit.gov.in /eg/article2.htm.

Dada, D. (2006). The Failure of E-Government in Developing. A Literature Review. The ElectronicJournal of Information Systems in Developing Countries. 22 (3).

Dwivedi, S.K. and Bharti, A.K. (2005) E-governance in India: problems and acceptability. Journal of Theoretical and Applied Information Technology, pp.37-43.

Enakrire, T. R. (2011). The Nigerian National Information Technology (IT) Policy. In Handbook of Research on Information Communication Technology Policy: Trends, Issues and Advancements (pp. 734-744). IGI Global. Retrieved 17 April, 2020 , from https://www.researchgate.net/publication/293308489_The_Nigerian_national_information_technology_IT_policy

Fatile, J.O. (2012). Electronic governance: myth or opportunity for Nigerian public administration. International Journal of Academic Research in Business and Social Sciences, Vol. 2 No. 9 pp.122-140

Farhanghi, A. A., Abbaspour, A., \& Ghassemi, R. A. (2013). The effect of information technology on organizational structure and firm performance: An analysis of Consultant Engineers Firms (CEF) in Iran. Procedia-Social and Behavioral Sciences, 81, 644-649. Retrieved 17 April, 2020, from https://www.sciencedirect.com/science/article/pii/S1877042813015577

Gberevbie, D.; Ayo, C.; Iyoha., Duruji M. \& Abasilim, U. (2015). E-Governance: Strategy for

Militating Non-Inclusion of Citizens in Policy Making in Nigeria. 15th European Conference on

e-Government, University of Portsmouth, United Kingdom, 18-19 June.

Gil-Garcia, J. R., Dawes, S. S., \& Pardo, T. A. (2018). Digital government and public management research: finding the crossroads. Retrieved 17 April, 2020, from https://www.tandfonline.com/doi/full/10.1080/14719037.2017.1327181

Godse, V. \& Garg, A. (2007). From e-Government to e-Governance. Retrieved from https://www.google.com.ng/?gfe_rd=cr\&ei=kreXVb2PEtLH8gft4YGwDw\&gws_rd=ssl\#q=godse+and+garg+2007

Heeks, R.B (2001), Building e-Governance for Development, iGovernment paper no.12, IDPM, University of Manchester

Holst, A. (2020). IT spending forecast worldwide 2015-2020. Retrieved $17 \quad$ April, 2020 , from https://www.statista.com/statistics/480063/worldwide-it-spending-forecast/

Kumar, M. (2020) An E-governance Model using Cloud Computing Technology for Developing Countries. Retrieved from Www.weblidi.info.unlp.edu.ar

Liu, S. M., \& Yuan, Q. (2015). The evolution of information and communication technology in public administration. Public Administration and Development, 35(2), 140-151.Retrieved $16 \quad$ April, 2020, from https://onlinelibrary.wiley.com/doi/abs/10.1002/pad.1717

Madugu, U. (2012) Application of information and communication technologies (ICTs) in the conduct of government business in Nigeria: implications for the bureaucracy. ABU Journal of Public Administration, Vol. 1 No.1 pp.122-141.

Mimbi, L., \& Bankole, F. O. (2016). ICT and public service value creation in Africa: Efficiency assessment using DEA approach. $\begin{array}{llll}\text { Retrieved } & 16 & \text { April, } & \text { from; }\end{array}$ https://ro.uow.edu.au/cgi/viewcontent.cgi?referer=https://scholar.google.com/\&httpsredir=1\&article=1016\&context=acis201 $\underline{6}$

Mittal, P. and Kaur, A. (2013). E-Governance: a challenge for India. International Journal of Advanced Research in Computer Engineering and Technology, Vol. 2, Issue 3, pp.1196-1199.

www.scirj.org

(C) 2020, Scientific Research Journal

http://dx.doi.org/10.31364/SCIRJ/v8.i5.2020.P0520774

This publication is licensed under Creative Commons Attribution CC BY. 
National information technology development agency (nitda). (2012). National Information and Communication Technology (ICT) Policy. Retrieved 17 April, 2020, from https://nitda.gov.ng/wp-content/uploads/2018/07/National-ICT-Policy1.pdf

Ojo, J. S. (2014). E-Governance: An Imperative for Sustainable Grassroots Development in Nigeria.Journal of Public Administration and Policy Research, vol. 6 (2), pp. 77-89.

Palvia, S. C. J., \& Sharma, S. S. (2007, December). E-government and e-governance: definitions/domain framework and status around the world. In International Conference on E-governance (No. 5, pp. 1-12).

Savic, D. (2006) E-governance: Theoretical Foundations and Practical Implications. Available at https://dobrica.savic.ca/pubs/egovernance_foundations.net.

Scupola, A., \& Zanfei, A. (2016). Governance and innovation in public sector services: The case of the digital library. Government

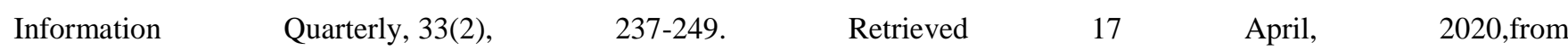
https://ro.uow.edu.au/cgi/viewcontent.cgi?referer=https://scholar.google.com/\&httpsredir=1\&article=1016\&context=acis201 $\underline{6}$

Shilubane, J. (2001). E-Government: An Overview, Service Delivery Review.A Learning Journal ofPublic Services Managers. Madugu (2012) Application of ICT in the conduct of government business and its implication on bureaucracy

www.scirj.org

(C) 2020, Scientific Research Journal

http://dx.doi.org/10.31364/SCIRJ/v8.i5.2020.P0520774

This publication is licensed under Creative Commons Attribution CC BY. 